\title{
Postcolonial Discourse in Coogler's Black Panther: A Multimodal Critical Discourse Analysis
}

\author{
Albert Tallapessy*; Indah Wahyuningsih; Riska Ayu Anjasari \\ Faculty of Humanities, Universitas Jember, Indonesia \\ *Corresponding Author: albert@unej.ac.id
}

\begin{abstract}
This article deals with the investigation of the existence of postcolonial discourse in Coogler's Black Panther (2018). The study aims to reveal and examine the existence of social issues related to Bhabha's notion of postcolonialism represented through visual and linguistic elements in the movie. Fairclough's $(1989,2001,2010)$ Critical Discourse Analysis, Kress and van Leeuwen's (2006) Reading Images, Halliday's Systemic Functional Linguistics (2004) and Bhabha's (1994) Postcolonialism are used to conduct this research. The result of the study shows that postcolonial discourse is proved represented in the movie. The findings imply that the post colonialism affects the characters in term of how they see and reflect themselves towards the dominance. They are also identified as possessing hybrid identity, ambivalence, and mimicry. It seems that the result of the research opposes the director's intention to bring the theme of the movie. Theoretically, it is proved that the social irregularities representing black supremacy and exploitation of the citizen of Africa, Wakanda, is depicted in the movie. Empirically, the existence of nondemocratic social practices in black citizens is also seen in the movie.
\end{abstract}

Keywords: postcolonialism; CDA; hybrid identity; ambivalence; mimicry; social irregularities; nondemocratic social practices

\section{INTRODUCTION}

Postcolonial discourse carries certain idea in constructing ideology through various media, mostly by using language as social practice (Hamadi, 2014:40). It consists of certain theories related to various approaches to analyze literary works concerning with the after European colonization and its effects towards the colonized's lives in general (Hamadi, 2014:39). The representation of postcolonial discourse today is seen on various media in which the western values become the core of representation. One of the media used is movie. As a popular culture product, movie does not only entertain the audience but also brings in a particular ideology. Black Panther, an afro futurist work, is proposed to be the icon of black liberation since afro futurism refers to a cultural change of primitive African to the technologically and scientifically advanced African to shape their own future through their imagination (Womack, 2013:152; Elia, 2014:84). However, instead of redefining their identity through the black liberation, the movie's story line shows an indication of Bhaba's postcolonial discourse in which even though they are depicted as technologically advanced African who are rich and powerful, they are influenced ideologically and culturally by the white supremacy. Moreover, it is also seen in the movie that black characters struggle to negotiate their voices in the midst of cultural differences against the superior. Thus, they use strategies to survive in the oppressive society who considers them as the Other. The strategies used by the inferior become threat to the superior as the values brought to the inferior culture are not seen as a holistic culture anymore.

This research is conducted to reveal postcolonial issues in the midst of African liberation of their culture. The study also attempts to examine how the postcolonial issues are represented through the language of the 
characters as well as the image through its semiotic elements of the selected scenes based on Halliday and Hasan's (1985) Generic Structure (GS).

To fulfill the goals, this research applied Fairclough's (1989) Critical Discourse Analysis (CDA) as the ground framework to disclose the practice of postcolonial discourse in the movie. Fairclough (1989) sees discourse through three dimensions as illustrated below:

Figure 1. Dimension of Discourse (Fairclough, 2001: 133)

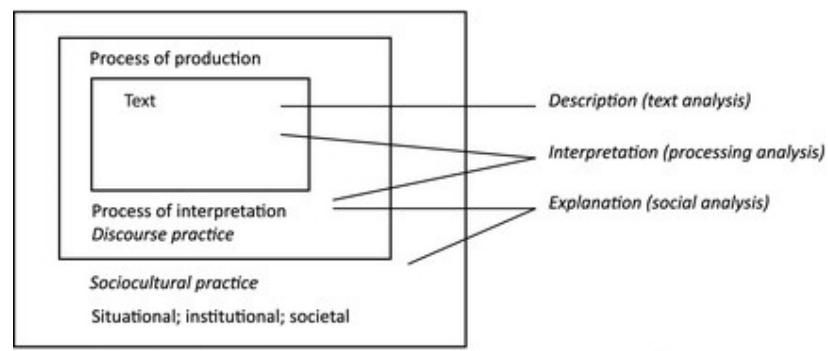

Accordingly, the analysis was done through the three dimensions of discourse. The first was text analysis focusing on the linguistics and visual features. The second was discursive practice analysis focusing on the text consumptions. The last was socio-cultural analysis focusing on the way the discourse produces and was produced through socio-cultural context.

The text analysis of the visual element was done by using Kress and van Leeuwen's (2006) Multimodality and Systemic Functional Visual Elements. It applied the three meta- functions (Kress and van Leeuwen, 2006: 42): representational (ideational) dealing with object representation and its relation with human experiences, interactional (interpersonal) meta function dealing with the relation of the producer of sign and the receiver or reproducer of that sign, and compositional (textual) metafunction functioned as the coherency tool to connect ideational and interpersonal metafunctions.

Similarly, the linguistic elements were analyzed using Halliday's (2004) metafunctions focusing on ideational and interpersonal meanings. The metafunctions were utilized to deconstruct meaning-making system by analyzing clauses from selected conversations based on their Generic Structure. They were used to reveal the hidden message beyond the clauses. Ideational function, known as transitivity system, is a system to construe meaning based on experiences which are realized through the chosen processes, while interpersonal metafunction or also known as mood and modality system is the system in which the relations between people are realized through proposal and proposition of clauses.

The second step of the analysis applied the notion of Bhabha's postcolonialism. The theory was used to reveal the structure and survival strategy of postcolonial representation in Black Panther. He believes that in the process of interaction between two different cultures (the colonized and the colonizer), both cultures influenced each other and accordingly, it can be said that there is no original culture. This study focuses on the terms of unhomeliness, mimicry, and hybridity. Mimicry refers to the desire of imitating colonizer's behavior, including their belief and culture and it is constructed as the result of ambivalence (Bhabha, 1994:86), which is the two opposing feelings of the colonized who do not like the colonizer's value but somehow admit that their value is right. Hybridity then becomes the revaluation of the colonized identity since they do not want to lose their own culture and they use this strategy to survive in the blended culture (Bhabha, 1994:112). On the other hand, Bhabha (2000) in Ghaffarpour (2013) stated that unhomeliness is the state in which the colonized get confused to find their worldview since their culture has been blended with the colonizer's culture in the process of colonization. They become psychological refugees of their own point of view (Ghaffarpour, 2013).

Finally, the socio-cultural context was used to apply the last dimension of Critical Discourse Analysis by Fairclough (1989). The context of the movie mostly shows the afro-futurist concept in which Wakandan is portrayed as the richest and the most technologically advanced colonized who still holds the tradition. The postcolonial discourse is seen through the struggle of King of Wakanda, T'challa, who defines what kind of king he wants to be as well as of Killmonger, the villain and the king's cousin, who struggles in finding a place called home. The other characters in the movie like Shuri, Nakia, Ross, and Klaue also represent the existence of postcolonial discourse, supporting the discourse presented by the main characters.

Besides the three dimensions of text, the spirit of Fairclough's CDA including the four stages for a more critical analysis of the study of language were applied (Fairclough, 2010: 217). They are as follows:

Stage 1 : Focus upon a social wrong, in its semiotic aspect.

Stage 2 : Identify obstacles to addressing the social wrong.

Stage 3 : Consider whether the social order 'needs' the social wrong.

Stage 4 : Identify possible ways past the obstacles. 
The stages are helpful to move from objective study of language to a more critical study of language, and to see the position of the writer.

This is a case study based on qualitative data. This study deals with the phenomenon related to postcolonial discourse presented through a particular fictional narration in a particular setting. The data were collected from a movie document (the original DVD) bought from the online shop. They are the linguistics and visual elements of the movie. After both elements were found, the data were selected from each element. The narrative structure of the movie was identified by using Halliday and Hasan's (1985) model of Generic Structure. The formula of the Generic Structure in the movie is shown in the following table.

Table 1. The Generic Structure of Black Panther

$$
\begin{aligned}
& \text { GS: } \mathrm{EX}^{\wedge} \mathrm{TS}^{\wedge} \mathrm{EX}^{\wedge} \mathrm{RA}^{\wedge} \mathrm{CX}^{\wedge} \mathrm{FA}^{\wedge} \mathrm{R}^{\wedge} \mathrm{TS} \\
& { }^{\wedge} \text { EndC } \mathrm{CS}^{\wedge} \mathrm{TS}^{\wedge} \mathrm{PostCS}
\end{aligned}
$$

Each symbol means as follows:

$\begin{array}{ll}\text { GS: Generic Structure } & \text { FA: Falling Action } \\ \text { EX: Exposition } & \text { R: Resolution } \\ \text { TS: Title Sequence } & \text { EndCS: End Credit Scene } \\ \text { RA: Raising Action } & \text { PostCS: Post Credit Scene } \\ \text { CX: Climax } & \wedge \text { : Followed by }\end{array}$

The collected data were processed through the following steps: breaking down the selected dialogues into clauses, labeling the selected shots using Systemic Functional Visual Elements in all metafunctions: representational, interactional, and compositional, and labeling the clauses using transitivity, mood and modality. The data were, then, analyzed through the three dimensions of Fairclough (1989)'s model of Critical Discourse Analysis (CDA). The first was describing the results of transitivity analysis, mood and modality analysis of the linguistics data as well as the visual data using systemic functional visual elements. The second was interpreting the results of analysis by combining them using Bhabha's perspective of postcolonialism and elaborating them to reveal the hidden message and ideology contained in the dialogues. The last was elaborating the interpretation by connecting them to the social-cultural context and the concept of postcolonialism based on Bhabha's perspective.

\section{DISCUSSION}

The following sections present the multimodal analysis of the selected scenes. Bateman and Schmidt's (2012) framework of Multimodal Film Analysis are used in companion with Halliday's Systemic Functional Linguistics described in the above section. The interaction between text and picture are presented by using tables and figures and then described to get the meaning. Theoretically, the description moves from lexicogrammar to context by using Halliday's (2014) model of Stratification and Realization.

Coogler's Black Panther speaks about the after effect of colonialism even though Wakanda is portrayed as a nation that has never been colonized. Both African and African-American are presented along with various political and social questions and issues regarding blacks' life in Africa and America in post-colonial era. Those issues become the focus of the analysis through the selected scenes.

\section{The One and the Other}

The Eldorado scene in Figure 2 is taken from Raising Action element. It indicates the existence of the shift from orientalism to in-betweeness. This can be underlined as the social wrong to see Wakanda as object by labelling it as Eldorado, a legitimate city to be exploited.

The act of orientalism, the way the world sees the colonized, is showed in this scene along with the shift from orientalism to hybridity. Moreover, it tells the world that Africa is not Africa anymore. The results of visual analysis in this scene are seen in Table 2.

The Table 3 is the analysis of the utterances which strongly suggests the existence of orientalism presented through the scene. There are 6 clauses analyzed by using ideational and interpersonal functions.

The scene (Figure 2) shows narrative actional process where Ross as the Actor interrogates Klaue as the Goal. The circumstance is accompaniment since T'Challa, Okoye, and Nakia present in the scene with the Actor and Goal, however they do not relate to the vector between Actor and Goal (Kress and van Leeuwen, 2006:72). As shown in table 6, the process used by Klaue is material process which functions to construe the act of doing and happening of outer experience (Halliday and Matthiessen, 2004:170) related to the hidden country, Wakanda. Ross uses attributive dominantly to relate participants towards its general description or characteristics (Butt et. al., 2000:58). Klaue's utterance what do you actually know about Wakanda? (see table 3.), triggers Ross to call out his knowledge in western's perspective about Africa in 
Figure 2. Shot Extract from Coogler's Black Panther (2018, 45:47-46:07), Eldorado Scene

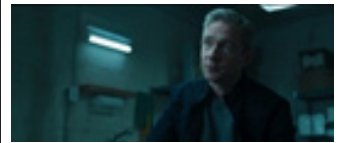

(1)

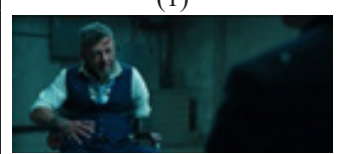

(4)

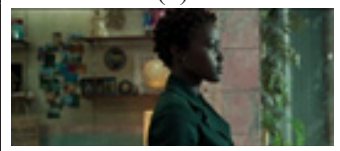

(6)

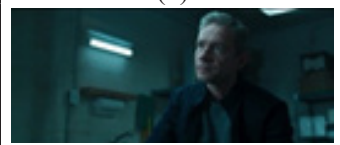

(10)

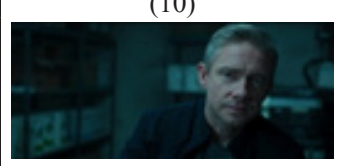

(14)

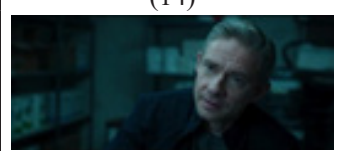

(18)

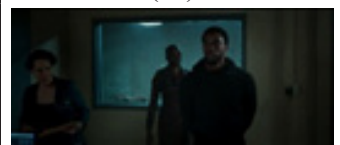

(22)

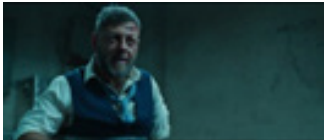

(2)
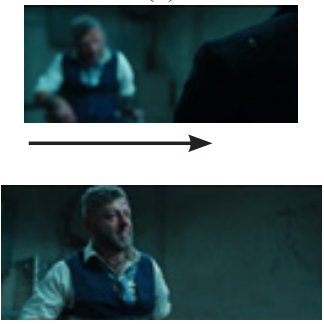

(7)

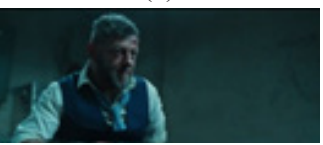

(11)

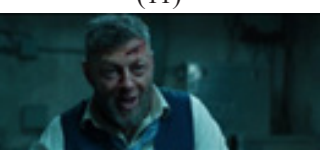

(15)

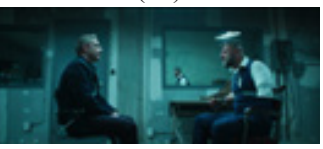

(19)

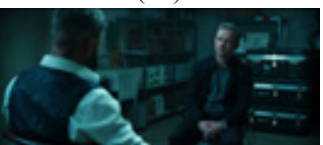

(23)

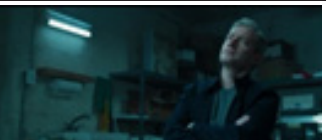

(3)

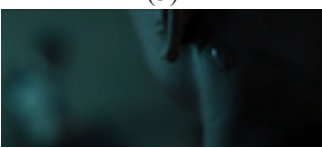

(5)

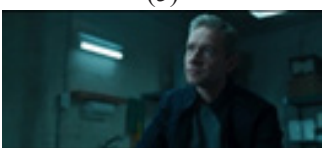

(8)

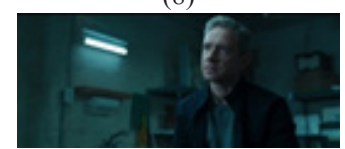

(12)

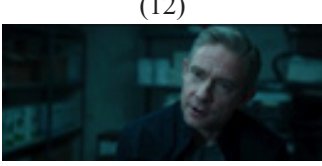

(16)

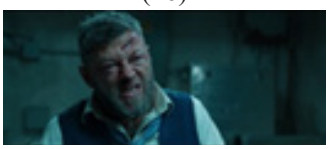

(20)
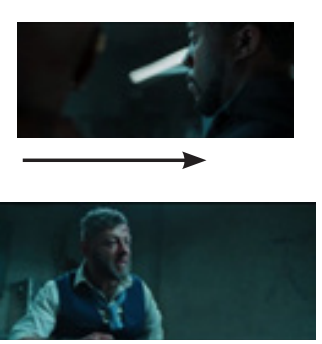

(9)

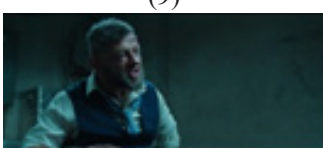

(13)

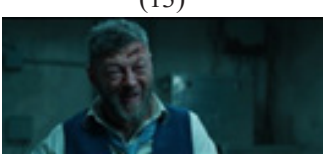

(17)

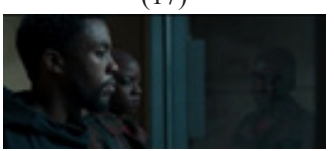

(21)

Table 2. The Visual Analysis of Eldorado scene

\begin{tabular}{|c|c|c|c|}
\hline \multirow{4}{*}{ Ideational Meaning } & \multirow{2}{*}{ Participants } & Actor & Ross \\
\hline & & Goal & Klaue \\
\hline & Process & Narrative & Action \\
\hline & Circumstance & Accompaniment & T'Challa, Okoye, Nakia \\
\hline \multirow{8}{*}{ Interpersonal Meaning } & \multirow{2}{*}{ Camera Movement } & Camera Stationary & 22 shots \\
\hline & & Camera Panning & 1 shot in (5) \\
\hline & Image Act & Offer & \\
\hline & \multirow{3}{*}{ Size of Frame } & Big Close Shot & 1 shot in $(5)$ \\
\hline & & Close Shot & 19 shots in (1) \\
\hline & & Medium Shot & 3 shots \\
\hline & Distance & Far Personal & 23 shots \\
\hline & Colour & Low Saturation & \\
\hline \multirow{3}{*}{ Textual Meaning } & \multirow{2}{*}{ Information Value } & Left & Klaue \\
\hline & & Right & Ross \\
\hline & Salience & Ross and Klaue & \\
\hline
\end{tabular}


Table 3. The Analysis of Clause 3 in Eldorado Scene

Klaue: |What do you actually know about Wakanda?||

\begin{tabular}{|l|l|l|l|l|l|}
\hline What & do & you & actually & know & about Wakanda? \\
\hline \multirow{3}{*}{ Wh } & Process & Senser & Circumstance & Mental & Phenomenon \\
\cline { 2 - 6 } & Finite & Subject & Adjunct & Predicator & Adjunct \\
\cline { 2 - 5 } & Mood: Interrogative & Residue & \\
\hline
\end{tabular}

Table 4. The Analysis of Clause 4 in Eldorado Scene

Ross: ||Ummm... Shepherds, textiles, cool outfits.\|

\begin{tabular}{|l|l|l|l|}
\hline Ummm... & $($ I & know) & sheperds, textiles, cool outfits. \\
\hline & Senser & Process: Mental & Phenomenon \\
\cline { 2 - 4 } & Subject & Finite & Complement \\
\cline { 2 - 4 } & Mood: Declarative & Residue \\
\hline
\end{tabular}

Table 5. The Analysis of Clause 5 in Eldorado Scene

Klaue: ||It's all a front. ||

\begin{tabular}{|l|l|l|}
\hline It & is & all a front \\
\hline Carrier & Process: Relational Attributive & Attribute \\
\hline Subject & Finite & Complement \\
\hline Mood: Declarative & & Residue \\
\hline
\end{tabular}

Table 6. The Analysis of Clause 6 in Eldorado Scene

Klaue: ||Explorers searched for it for centuries, Eldorado, the Golden City.\|

\begin{tabular}{|l|l|l|l|l|}
\hline Explorers & searched & for it & for centuries & Eldorado, the Golden City \\
\hline Actor & Process: Material & Goal & Circumstance: Place & Goal \\
\hline Subject & Finite & Complement & Adjunct & \\
\hline Mood: Declarative & Residue &
\end{tabular}

Table 7. The Analysis of Clause $19 \& 20$ in Eldorado Scene

Ross: |That's a nice fairy tale ||but Wakanda is a third world country\|

\begin{tabular}{|c|c|c|c|c|c|c|}
\hline That & is & a nice fairy tale & but & Wakanda & is & a third world country \\
\hline Carrier & $\begin{array}{l}\text { Process: Relational } \\
\text { Attributive }\end{array}$ & Attribute & & Carrier & $\begin{array}{l}\text { Process: Reational } \\
\text { Attributive }\end{array}$ & Attribute \\
\hline Subject & Finite & Complement & & Subject & Finite & Complement \\
\hline \multicolumn{2}{|c|}{ Mood: Declarative } & Residue & & \multicolumn{2}{|c|}{ Mood: Declarative } & Residue \\
\hline
\end{tabular}


general. Then he refers them to shepherds, textiles, cool outfit. However, Klaue attributes them as Eldorado, the golden city. According to Bhabha (1994:42) the past or colonial era ties up to unfair stereotypes of primitivism and degeneracy from the colonizer's point of view. It affects how the colonized sees themselves and disturbs their view about themselves. In addition, the movie also represents the reaction of Wakandan by showing them through close shot. It can be related to the shift of binary opposition to in-betweeness. From the colonizer's gaze when the colonized are dominated through such stereotyping, the colonized then plays cultural strategy to negotiate their voice (Bhabha, 1994:1).

\section{Unhomeliness: the Estrangement of Received Tradition}

This scene is taken from Falling Action element. It portrays the unhomely representation of the diaspora character. This stage 2 identifies obstacles to address the social wrong. Even Erick who is also Wakandan sees his home as an object to rule, not a place to come home in peace.

The scene in Figure 3 shows the act of Erik who is recalling his past life with his father in his hometown. It expresses his unhomeliness. Erik gets confused of his identity. He is politically the King of Wakanda but he

Figure 3. Shot Extract from Coogler' Black Panther (01: 26-01:28), Erik Unhomeliness Scene

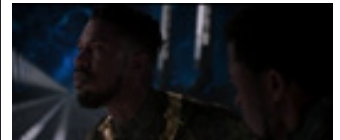

(1)

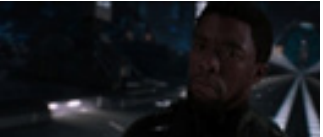

(2)

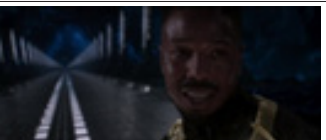

(3)

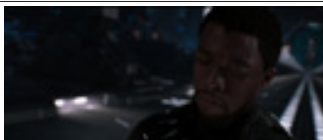

(4)

Table 8. The Visual Analysis of Erik's Unhomeliness Scene

\begin{tabular}{|l|l|l|l|}
\hline \multirow{4}{*}{ Ideational Meaning } & \multirow{2}{*}{ Participants } & Actor & Erik \\
\cline { 2 - 4 } & & Goal & T'Challa \\
\cline { 2 - 4 } & Process & Narrative & Action \\
\cline { 2 - 4 } & Circumstance & Accompaniment & T'Challa \\
\hline \multirow{5}{*}{ Interpersonal Meaning } & Camera Movement & Camera Stationary & 4 shots \\
\cline { 2 - 4 } Textual Meaning & Image Act & Offer & \\
\cline { 2 - 4 } & Size of Frame & Close Shot & 4 shots \\
\cline { 2 - 4 } & Distance & Close Personal & Erik (1) \\
\cline { 2 - 4 } & Colour & Low Saturation & T'Challa, Erik (3) \\
\hline \multirow{5}{*}{\begin{tabular}{l} 
Information Value \\
\cline { 2 - 4 }
\end{tabular}} & Left & Right & \\
\cline { 2 - 4 } & Salience & Erik & \\
\hline
\end{tabular}

Table 9. The Analysis of Clause 6 in Erik's Unhomeliness scene

Erik: ||You believe that? | Kid from Oakland is running around believing in fairy tales $\|$

\begin{tabular}{|l|l|l|l|l|l|l|}
\hline You & believe & that? & kid from Oakland & Is & running around & believing in fairy tales \\
\hline Senser & $\begin{array}{l}\text { Process: } \\
\text { Mental }\end{array}$ & Phenomenon & Actor & $\begin{array}{l}\text { Process: } \\
\text { Material }\end{array}$ & $\begin{array}{l}\text { Circumstance: } \\
\text { Cause }\end{array}$ & \\
\hline Subject & Finite & Complement & Subject & Finite & Predicator & Adjunct \\
\hline $\begin{array}{l}\text { Mood: } \\
\text { Interrogative }\end{array}$ & & Residue & & $\begin{array}{l}\text { Mood: } \\
\text { Declarative }\end{array}$ & Residue & \\
\hline
\end{tabular}


feels like he is not Wakandan but American. The visual analysis is as follows (Table 8).

Table 8 above shows that the scene is indicated as narrative actional process where Erik is the Actor and T'Challa is the Goal. Erik shows T'Challa his emotional state of unhomeliness. The circumstance showed here is an accompaniment that T'Challa is considered as not only a Goal but also a vector in the shot (1). The visual element suggests the emotional state of both characters. It is showed by the expression of the characters. It is supported by the linguistic element which indicates unhomely representation. Accordingly, the African immigrant or the African diaspora feels unfamiliar with African culture even though they are biologically African. Erik, the one who represents diaspora subject in this movie, experiences the estrangement between America and Africa, between him and T'Challa. This can be identified from his statement that considers Wakanda as fairy tale and attributes himself as kid from Oakland as shown by the Table 9 .

This scene portrays the state where the diaspora subject rewrites his identity through the condition of contradictoriness which emerging from the interaction between the host and the minorities. This process estranges himself from any immediate access to an original identity or received tradition (Bhabha, 1994:2). This indicates that Erik feels unhomely by recalling his hometown although he is the king of Wakanda. The confrontation of the colonizer's culture in the colonization makes the colonized subject confused of his identity or his own worldview (Ghaffarpour, 2013:94). This state of confusion is in line with what Bhabha calls unhomeliness (Bhabha, 1994: 9-11).This condition makes Erik a psychological refugee (Ghaffarpour, 2013:91).

\section{Mimicry as the Strategy of Negotiating Culture}

The scene that represents mimicry as the strategy of negotiating culture below is taken from Exposition element. This stage 3 considers whether the social order 'needs' the social wrong. American sees Erik is more American than Wakandan. Hence, white people are not one hundred percent wrong for their bad conduct in the past, since it is a family problem, and at the end of the movie they can exploit the advance technology needed for the open world. The shot extract presented in this scene can be seen in Figure 4.

The shot in Figure 4 shows that Erik is in the Museum of Great Britain, having argument with a museum curator. His utterances express as if he was in the colonial era where British Empire ruled Africa. It indicates that Erik is imitating the colonizer's view to conquer the world for his personal political desire and it is seen as the voice of ambivalence. The results of visual analysis are showed below.

There are 6 clauses uttered by Erik to the museum curator. The metafunctions' analysis is presented in the Tables 11-13.

Table 10 shows the process of action where Erik is the Actor while the curator is the Goal. The process is narrative representation involving the patterns to present unfolding actions and events, process of change, transitory spatial arrangements (Kress and van Leeuwen, 2006:59). Erik's utterance How do you think your ancestors got these? has an effect towards Erik to call out again the struggle of his ancestors in the time of colonization since the word think is a mental process meaning that it has to do with cognitive process involving the senser you (the curator) and the phenomenon your ancestor got this. The utterances following the questions have the same effect to disclose Erik's feeling towards colonizer. The utterances show the conquest and the power over the trade and donation in which Erik's contradictive feeling of love and hatred towards the colonizer is seen simultaneously as ambivalence (Ghaffarpour, 2013:91). This kind of feeling triggered the will to imitate the colonizer as a strategy to make themselves exist in the dominant power and culture. Bhabha (1994:86) stated that "the discourse of mimicry is constructed around ambivalence." This kind

Figure 4. Shot Extract from Coogler' Black Panther (15:40-17:00), Museum Scene

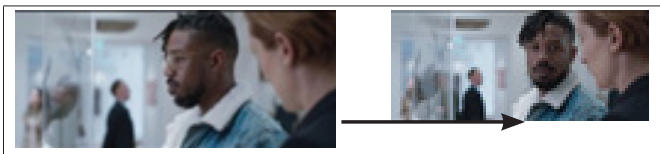

(1)

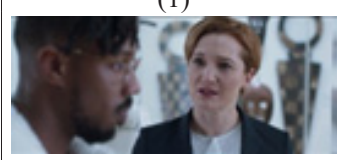

(4)

(5)

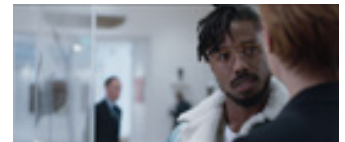

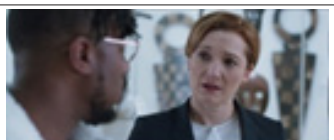

(2)
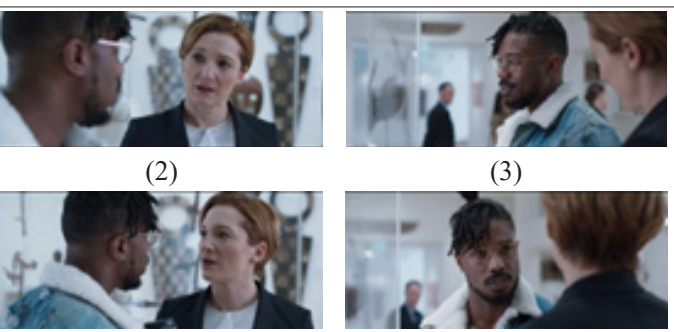

(6)
(3)

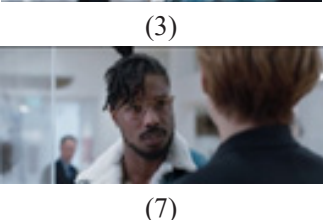


Table 10. The Visual Analysis of Museum Scene

\begin{tabular}{|l|l|l|l|}
\hline \multirow{4}{*}{ Ideational Meaning } & \multirow{2}{*}{ Participants } & Actor & Erik \\
\cline { 2 - 4 } & & Goal & The staff \\
\cline { 2 - 4 } & Process & Narrative & Action \\
\cline { 2 - 4 } & Circumstance & Locative & Foreground \\
\hline \multirow{5}{*}{ Interpersonal Meaning } & Camera Movement & Camera Stationary & 7 shots \\
\cline { 2 - 4 } & Image Act & Offer & \\
\cline { 2 - 4 } Textual Meaning & Size of Frame & Close Shot & 7 shots \\
\cline { 2 - 4 } & Distance & Close Personal & 7 shots \\
\cline { 2 - 4 } & Colour & Medium Saturation & \\
\hline \multirow{5}{*}{} & Information Value & Left & Thik \\
\cline { 2 - 4 } & & Right & \\
\cline { 2 - 4 } & Salience & Erik & \\
\hline
\end{tabular}

Table 11. The Analysis of Clause 7 in Museum Scene

Erik: || How do you think [[your ancestors got these (?)]] ||

\begin{tabular}{|l|l|l|l|l|l|l|}
\hline How & do & you & think & your ancestor & got & these ? \\
\hline Wh. & Process:... & Senser & ...Mental & ...Phenomenon & & \\
\hline & & & & Actor & Process: Material & Goal \\
\hline Wh. & Finite & Subject & Predicator & ...Complement & & \\
\hline Re- & Mood: Interrogrative & & -sidue & ...Residue & & Complement \\
\hline & & & & Subject & Finite & \\
\hline
\end{tabular}

Table 12. The Analysis of Clause 9 and 10 in Museum Scene

Erik: ||You think [[they paid a fair price?]] |||

\begin{tabular}{|l|l|l|l|l|}
\hline You & think & they & Paid & a fair price? \\
\hline Senser & Process: Mental & Phenomenon & & \\
\hline \multirow{2}{*}{ Subject } & & Actor & Process: Material & Range \\
\hline \multirow{2}{*}{ Mood: Interrogrative } & Finite & Complement & & \\
\cline { 2 - 4 } & Residue & & \\
\cline { 2 - 5 } & Subject & Finite & Complement \\
\cline { 2 - 5 } & Mood: Interrogrative & & Residue \\
\hline
\end{tabular}

Table 13. The Analysis of Clause 11 in Museum Scene

Erik: ||Or they take it ||like they took everything else?

\begin{tabular}{|l|l|l|l|l|l|l|l|}
\hline or & they & take & it & like & they & took & everything else? \\
\hline Conj. & Actor & Process: material & Goal & Conj. & Actor & Process: material & Goal \\
\hline & Subject & Finite & Complement & & Subject & Finite & Complement \\
\hline Re- & $\begin{array}{l}\text { Mood: } \\
\text { interrogrative }\end{array}$ & & -sidue & & Re- & $\begin{array}{l}\text { Mood: } \\
\text { interrogative }\end{array}$ & -sidue \\
\hline
\end{tabular}


of imitation is called mockery. In this situation, Erik, the only Wakanda diaspora presented in the movie, has the capacity to enter the dominant culture by negotiating his voice.

\section{Hybridity: Globalization versus Isolation}

This scene shows the final stage (stage 4) of the story. Wakanda knows that the moral compass should be on humanity, thus they are ready to share the technology to the open world, but they don't share the vibranium as the energy source of their advance technology. The global world needs to know that Wakanda is sophisticated but they are still isolating themselves for sharing the vibranium. The interpretation of the Oakland scene depicts the process of globalization of Wakanda and the reaction of Oakland's neighborhood children of the revealing identity. Here are some selected shots in this scene.

This act starts from the establishment of Wakanda outreach center for underprivileged children of Oakland. The result of visual element analysis is presented below.

The Tables 15 show the analysis of the characters' dialogues. The clauses are analyzed in terms of transitivity and mood.

The scene shows the narrative reactional process where the Oakland kids function as the reactor and T'Challa, Shuri, and a Wakandan ship are the phenomenons. The circumstance is locative, showing the surrounding of Oakland neighborhood. The visual representation attempts to show the realization of
Wakandan isolation that even the people themselves do not know who they are and what technology they use. It is supported by the children's utterances indicating the absence of T'Challa's identification. The reaction showed by the children is seen through the interrogative mood like Where are you from? What is a Wakanda? Who are you, which are categorized as relational processes. Relational process functions as a connector to provide a new identity or to relate a participant to its general characteristics or descriptions (Butt, et. al., 2000:58-59). The reaction is also presented through the shots showing the location by utilizing long shot and camera dollying as the strategy to take the scene as vividly as possible. The interplay between the visual and linguistic elements depicts the sign that Wakanda is strange to them because of isolation. Accordingly, the negotiation of mother culture reappears again in the self of diaspora subject presented through the self of Oakland kids. The social articulation of differences from the minority perspective (in this case children of Oakland perspective) is a complex, on-going negotiation that seeks authorization of cultural hybridity emerging in moments of historical transformation (Bhabha, 1994:2).

This scene depicts the globalization as part of hybrid culture as well as emphasizes the setting and its surroundings. The underprivileged African-American living in Oakland has a long history. It is the establishment of Black Panthers party in the city which happened in 1960s, defending the black's right and fighting for those who were treated unfairly. Accordingly, this scene strongly suggests the same notion of Black Panthers party's aims which are portrayed by Wakanda in this movie.

Figure 5. Shot Extract from Coogler' Black Panther (14:37-15:20) Oakland Scene

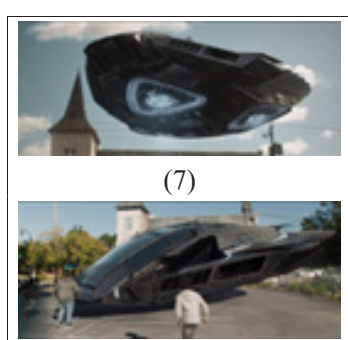

(11)

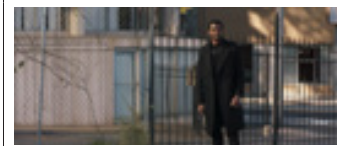

(15)

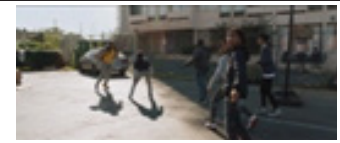

(8)

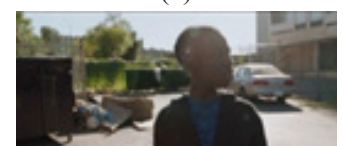

(12)

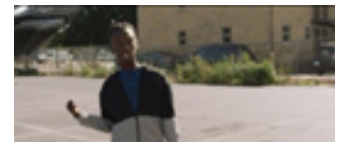

(16)

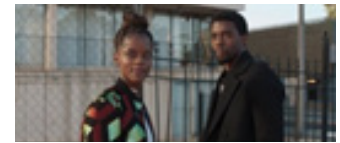

(9)

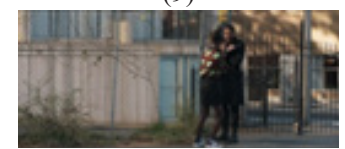

(13)

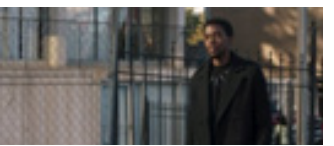

(17)

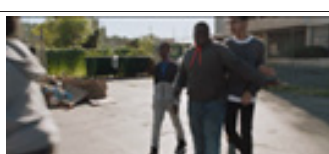

(10)

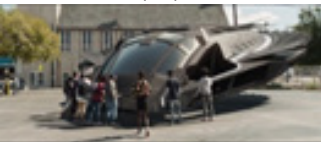

(14)

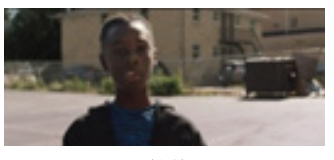

(18) 
Table 14. The Visual Analysis of Oakland Scene

\begin{tabular}{|c|c|c|c|}
\hline \multirow{4}{*}{ Ideational Meaning } & \multirow[b]{2}{*}{ Participants } & Reacter & The neighborhood kids \\
\hline & & Phenomenon & $\begin{array}{l}\text { Wakandan Ship, T'Challa } \\
\text { and Shuri }\end{array}$ \\
\hline & Process & Narrative & Reactional \\
\hline & Circumstance & Locative & $\begin{array}{l}\text { Wakandan ship and the } \\
\text { neighborhood }\end{array}$ \\
\hline \multirow{11}{*}{ Interpersonal Meaning } & \multirow{3}{*}{$\begin{array}{l}\text { Camera } \\
\text { Movement }\end{array}$} & Camera Stationary & 7 shots \\
\hline & & Camera dollying & 4 shots in $(8),(10),(16),(17)$ \\
\hline & & Camera Tilting & 1 shot in $(7)$ \\
\hline & Image Act & Offer & \\
\hline & \multirow{3}{*}{ Size of Frame } & Close Shot & 3 shots \\
\hline & & Medium Shot & 2 shot \\
\hline & & Long Shot & 7 shots \\
\hline & \multirow{3}{*}{ Distance } & Close Personal & 2 shots in $(9),(12)$ \\
\hline & & Far Personal & 3 shots in $(16),(17),(18)$ \\
\hline & & Far Social & 7 shots \\
\hline & Colour & High Saturation & \\
\hline \multirow{3}{*}{ Textual Meaning } & \multirow{2}{*}{$\begin{array}{l}\text { Information } \\
\text { Value }\end{array}$} & Left & - \\
\hline & & Right & - \\
\hline & Salience & The neighborhood kids & \\
\hline
\end{tabular}

Table 15. The Analysis of Clause 13 in Oakland Scene Kids: |where are you from?\|

\begin{tabular}{|l|l|l|l|}
\hline Where & Are & You & from? \\
\hline Wh & $\begin{array}{l}\text { Process: Relational } \\
\text { Attributive }\end{array}$ & Carrier & Attribute \\
\hline & Finite & Subject & Adjunct \\
\hline & Mood: Interrogative & & Residue \\
\hline
\end{tabular}

Table 16. The Analysis of Clause 14 in Oakland Scene Shuri: ||from Wakanda\|

\begin{tabular}{|l|l|l|}
\hline (I & am) & from Wakanda \\
\hline Carrier & $\begin{array}{l}\text { Process: Relational } \\
\text { Attributive }\end{array}$ & Attribute \\
\hline Subject & Finite & Adjunct \\
\hline $\begin{array}{l}\text { Mood: } \\
\text { Declarative }\end{array}$ & Residue & \\
\hline
\end{tabular}

Table 17. The Analysis of Clause 15 in Oakland Scene Kids: |what is a Wakanda?\|

\begin{tabular}{|l|l|l|}
\hline What & Is & a Wakanda? \\
\hline Wh/Carrier & $\begin{array}{l}\text { Process: Relational } \\
\text { Attributive }\end{array}$ & Attribute \\
\hline Subject & Finite & Complement \\
\hline \multicolumn{2}{|l}{ Mood: Declarative } & Residue \\
\hline
\end{tabular}

Table 18. The analysis of clause 17 in Oakland scene The boy: |Who are you?\|

\begin{tabular}{|l|l|l|}
\hline Who & Are & you? \\
\hline Wh/Value & $\begin{array}{l}\text { Process: Relational } \\
\text { Identifying }\end{array}$ & Token \\
\hline Wh & Finite & Subject \\
\hline $\begin{array}{l}\text { Residue } \\
\text { Mood: Declarative }\end{array}$ & \\
\hline
\end{tabular}




\section{The Socio-Cultural Context and Postcolonial Discourse in Coogler's Black Panther}

This section presents the socio-cultural context of the movie by relating the findings at the level of text and discursive practice. The movie presents the historical background of colonization era which influences the life of the colonized Africa. The frustrations of AfricanAmerican and the diaspora experience of colonization and even slavery are also presented. It is known that in the real world, Africa and America were colonized by British Empire. As shown in the first selected scene, Erik saw the artefacts of African origin when he visited Museum of Great Britain and claimed that those things were taken by the colonizer. This is the actual representation of African colonization history.

Accordingly, Wakanda in the movie is the representation of the land of the native of North America whose name of their God is Wakanda. A report in 1873 called The Far West in Nashville Tennessee stated that there was a future state which was the place of joy and peace and there were courageous warriors called Wakan-da whom Tennessean also called "the country of life." (Manseau, 2018). Besides, Wakanda society was portrayed as a complex society of different factions of group of people. There were five tribes living in Wakanda. (Eckhardt, 2018:2). In short, it can be concluded that the idea of utopian nation of a marginalized culturally complex society is presented in the movie which is trying to negotiate a mother culture to the world. It is seen as a result of discursive effects of colonialism and contemporary displacements which bring the Wakandan to the moment of transit in which time and space are crossing to produce complex figures of difference and identity (Bhabha, 1994:1).

The setting of Wakanda in the movie represents Oakland as a place of diasporic subject. In fact, Oakland is the hometown of the director of the movie, Ryan Coogler, who is an African-American. In 1966, a party called Black Phanter whose purpose was to defend and fight for the black's right in America was noted. In the same year, Black Panther was created by Jack Kirby and Stan Lee as the first Coogler's black superhero. It seems that the characters in the movie are inspired by the party. The histories of both Black Phanters are intertwined, yet they cannot be identified clearly. The representation of a Wakandan named Eldorado, the excellent black, and the party fighting for the black's right shows that the black's civilization might be preserved if the white did not colonize them. Similarly, both Black Panthers try to present the blacks' lives in the world where blacks are marginalized.

The visual and linguistics element analysis shows that the diaspora character presented by Erik gets difficulties to find a place called home. Erik's unhomeliness scene tells that there is difference between native African and African diaspora. A negative character represented by Erik is a stereotype of an African-American, whereas a degenerated character in the United Nation scene is represented by Eldorado.

On the other hand, the complex character presented by the villain, Erik Killmonger, depicts the political desire to dominate the world using the colonizer's strategy. Wakandan empire scene strongly suggests this complexity of postcolonialism where the subject of colonialism utilizes the empowerment of society to fulfill his personal political desire. Bhabha (1994:171) sees the postcolonial perspectives emerge from the colonial evidence of the Third World countries along with the discourse of 'minorities' in which the hegemonic 'normality' is given. The colonized then formulates the critical revisions around the issues of social authority, cultural difference, and political discrimination to reveal the antagonistic and ambivalent moments. These revisions mean that the postcolonial subject, Erik, imitates the colonizer with his mentality as a product of America's racial experience to gain a complex perspective on how to empower people of color. However, his decision to dominate the world through fear and hate and the revision comes to the point where his act is no longer for the sake of people of color but most-likely for his personal political desire. This is how dictatorship is born in postcolonial country. In fact, Africa has faced a lack of democratic political institutions as the result of the adoption of former colonizer's system (Wong, 2017).

Another issue presented through the movie is the liberation of the blacks which is hard to obtain in America. The theme of afro-futurist film brought the notion of the liberation of African culture. However, it does not have a significant effect towards the right of the blacks yet, despite the development of perspectives that consider blacks matter has been increasing from decade to decade. Black Panther is probably the best Coogler's film directed by a black man, but the film does not necessarily change the way the world treats minorities and women and the struggle of minorities and women to fight for equality (Gottlieb, 2018). This is proven through the confusion of the characters in defining their own culture and belief as the effect of colonization showed through the museum scene.

Postcolonial discourse in Bhabha's ideas, in this 
case unhomeliness, mimicry, and hybridity, is found in the film and it has been proven through the analysis of visual and linguistic elements. The linguistic and visual element analyses show that the interplay between those elements construct the idea of postcolonial discourse used by the director to represent black culture in the movie. The postcolonial issue in the movie indicates the hybrid identity of the African and it is in line with what happens to the descended Africa in the world context either by Erik as an African-American or by T'Challa as an African.

\section{CONCLUSION}

Based on the above discussion, it is concluded that Fairclough's CDA and Halliday's SFL have worked to construe the meaning of Black Panther. At the level of text, the analysis of metafunctions enable us to reveal the message based on what language is functioning in the movie. Multimodality is crucial to uncover the textual function due to multimodal mode that the film has. At the level of discursive practice, Bhabha's notion of Postcolonialism discloses the postcolonial representation in this one of most successfully Coogler's movies. At the level of social practice, the scenes addresses the issues of colonialization, the struggle of African diaspora, the fight of blacks to present their voice in the midst of dominated culture, the issue of dictatorship as the result of the complexity of postcolonialism, and even the issue of globalization versus isolation. The finding suggests that the representation of the postcolonial discourse shows the postcolonial subject's confusion of his identify. It means that the director fails to present the liberation of African culture.

Fairclough CDA unveils Cooglers' idea that it is an obligation of Wakanda to share his marvelous technology to open world. Klaue, a world class criminal, sees Wakanda as Eldorado and is not merely a third world poor country. Klaue wants to exploit Wakanda advance technology and natural resources but ironically this idea is more explicated through a more dramatic character named Erik, a lost living wakanda descendant, with his family drama and conflict prince T.Challa, a rightful heir of wakanda (first stage, focus upon a social wrong,). Erik shares the idea to see Wakanda not as a home but a land to a rule depicted through his mimicry scene in British Museum (stage: 2, identify obstacles to addressing the social wrong.). His negotiating value to rule Wakanda and to conquer the world become the legitimate reasons that Wakanda needs a more moderate king who is able to share the technology to the open world (step 3: consider whether the social order 'needs' the social wrong). It is impliedly saying that T.Challa distributes technology not because of force of the open world but from his own wisdom. Despite his past internal conflict, history with the open world, and Klaue's information to Erik which triggers the "civil war" in Wakanda, Coogler's Black Phanter legitimates the notion that it is a must for Wakanda to share their technology by neglecting the series of action done by Klaue, and open the world to their country. The postcolonial spirit is depicted by the power of T' Challa to share the technology they have but not by the energy source which needs to be kept secret (stage 4: Identify possible ways past the obstacles.).

Black Panther should still be seen as an American film production in which although it seems to want to show the superiority of blackness and the loss of racism, at the end its story appears to be technological exploitation as expected by Klaue, as an open world representation. Thus, once again black citizens must drain their energy for external interests despite the burden of the past in voluntary ways.

The three Fairclough's conceptual tools, multimodality, and Bhaba's postcolonialism are able to sharpen the analysis. Multimodality helps show the dimensions of the initial text as well as objective analysis of the text at the micro level. CDA shows the social irregularities in Black Panther which seems to show black supremacy but at the end of the story, it has exposed the intention of open world to continue to exploit the citizens of Africa, Wakanda. Postcolonialism helps show the agency and the spirit of resistance through negotiating Wakanda with the open world, not by showing the source of their energy, but only by the sophistication of their civilization.

Empirically Black Panther indicates that American films have not moved to present the hierarchical position of black citizens to continue to volunteer to give what they have to the world civilization. At the same time the film still wants to show the existence of non-democratic social practices in black citizens who are very likely to be rewarded uncivilized through a battle between T'Challa and Erik when fighting for power. This representation is not good because it still attaches the image that Wakanda still cannot be separated from uncivilized practices, no matter how powerful the country is.

\section{REFERENCES}

Bateman, John A and Schmidt, Karl-Heinrich (2012). Multimodal Film Analysis How Film Means. New York: Routledge.

Bhabha, H. K. (1994). The Location of Culture. New York: 
Routledge.

Butt, D., Fahey, R., Frez, S., Spinks, S., \& Yallop, C. (2003). Using Functional Grammar: An Explorer's Guide. 2nd ed. Sydney: National Centre of English Language Teaching and Research Macquarie University.

Eckhardt, G. M. (2018). Black Panther: Thrills, Postcolonial Discourse, and Blacktopia. Markets, Globalization and Development Review: Vol.3: No.2, Article 6. DOI 10.23860/MGDR-2018-03-02-06.

Elia, A. (2014). The Language of Afrofuturism. Linguee Linguaggi, 12, 83-96. DOI 10.1285/ i22390359v112p83.

Fairclough, N. 1(989). Language and Power. London: Longman.

Fairclough, N. (2001). Critical Discourse Analysis as A Method in Social Scientific Research. In Methods of Critical Discourse Analysis. Edited by Wodak, R. and Meyer, M.London: Sage Publications.

Fairclough, Norman (2010). Critical Discourse Analysis, the Critical Study of Language. London: Routledge.

Feige, Kevin (Producer), Coogler, Ryan, Cole,Joe Robert (Directors) (2010). Black Panther (DVD). Burbank: Marvel Studios.

Ghaffarpour, R. (2013). A Postcolonial Appraisal of Suzanne Collins' The Hunger Games in The Light of Bhabha's Ideas. International Journal of Applied Linguistics and English Literature, 2(4), 90-97. DOI:10.7575/ aiec.ijalel.v.2n.4p.90.

Gottlieb, J. (2018). "Black Panther" Is Already a Hit, but It Won't Change the Way Hollywood Treats Minorities and Women. https://qz.com/quartzy/1202764/ black-panther-is-already-a-hit-but-it-wont-changethe-way-hollywood-treats-minorities-and-women/ [accessed on 16 December 2018]
Halliday, M.A.K and Hasan Ruqaiya (1985). Language, Context and text: Aspect of Language in Socialsemiotic Perspective. Melbourne: Deakin University Press.

Halliday, M. A. K., and M. I. M. M, Christian (2004). An Introduction to Functional Grammar. 4th ed. Oxford University Press.

Hamadi, L. (2014). Edward Said: The Postcolonial Theory and The Literature of Decolonization. European Scientific Journal, 2, 39-46. e-ISSN 1857-7431.

Kress, G. (2010). Multimodality: A Social Approach to Contemporary Communication. Britain: Routledge.

Kress, G.,and Leeuwen, T. V. (2006). Reading Images: The Grammar of Visual Design. Canada: Routledge.

Manseau, P. (2018). The Surprising Religious Backstory of 'Black Pather's' Wakanda. https://www. washingtonpost.com/news/acts-of-faith/ $\mathrm{wp} / 2018 / 03 / 07 /$ the-surprising-religious-backstoryof-black-panthers-wakanda/?noredirect=on\&utm term $=$. bb40fcf36957. [acessed on 16 December 2018]

Sasani, S. (2015). A Postcolonial Reading of Pygmalion: A Play of 'Mimicry'. International Journal of Applied Linguistics and English Literature, 4(2), 238-245. DOI:10.7575/aiec.ijalel.v.4n.2p.238.

Womack, Y. L. (2013). Afrofuturism: The World of Black SciFi and Fantasy Culture. Journal of Electronic Dance Music Culture, 5(2), 152-168. DOI:10.12801/19475403.2013.05.02.08.

Wong, D. (2017). The Colonial Nature of African Dictatorships. [accessed on 12 April 2019] 